\title{
Tecnologia da Informação e Comunicação a Serviço da Aviação
}

\begin{abstract}
A aviação mundial muito evoluiu desde os tempos de Santos Dumont, hoje em dia, existe um aporte tecnológico de última geração a bordo das aeronaves que cruzam nossos céus, transportando pessoas e cargas de um extremo ao outro da esfera terrestre.

Com a crescente evolução tecnológica não era de se esperar que as aeronaves fossem beneficiadas com tecnologia de ponta, muitos comandos manuais e sensores analógicos chegam à era digital, agora o comandante precisa preocupar-se com o que é mais importante, que é transportar passageiros e cargas com segurança e eficiência.

Junto com esta tecnologia surgem os dados, oriundos dos sistemas digitais embarcados, onde ao término de uma viagem a empresa aérea, não apenas tem acesso a um conjunto de informações analisadas, como dados obtidos a partir de telemetria, equipamentos e outras fontes. Informações e dados que ajudarão técnicos e especialistas a entenderem melhor o dia a dia das aeronaves e descobrirem eventuais problemas e pontos de atenção de maneira mais assertiva para evitar atrasos e problemas para os passageiros.

Todas estas informações coletadas podem servir para auxiliar na predição de falhas, através na mineração e classificação de dados, redes neurais e sistemas inteligentes, tornando possível a detecção de um mau funcionamento em algum mecanismo e, em um futuro próximo, predizer possíveis falhas, auxiliando na gestão de risco, antes mesmo destas se manifestarem fisicamente na aeronave.

Quando pensamos em tecnologia a bordo na aviação logo pode vir à nossas mentes os sistemas de entretenimento que as aeronaves mais modernas nos apresentam como uma fuga ao tédio das longas viagens intercontinentais, porém, imaginando um passando não muito distante, as aeronaves mal possuíam um sistema de comunicação entre a tripulação e a cabine, e hoje até mesmo as instruções de segurança nos são informadas por vídeos com animações mais chamativas.

O conceito de tecnologia a bordo também não está limitado ao fato de podermos realizar chamadas telefônicas em pleno voo, ou acessar a internet através do WIFI de bordo, por trás de tantos sensores, dispositivos elétricos e mecânicos, existe um sistema computacional capaz de
\end{abstract}

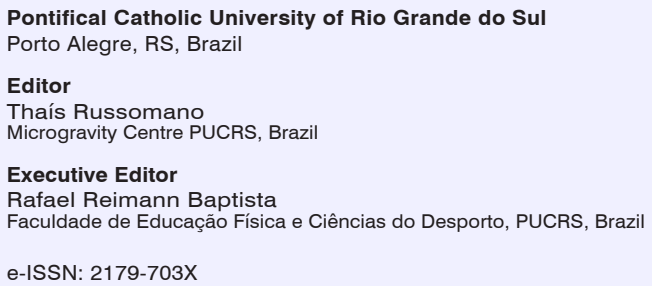

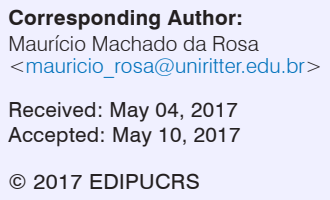


informar ao piloto, em tempo próximo ao real, sobre as condições da aeronave e ainda condições externas à aeronave, auxiliando na predição de tempestades e possíveis áreas de turbulência.

A mineração de dados, em um futuro muito próximo, nos possibilitará, aliada com análises estatísticas e machine learning analisar todas as falhas já ocorridas, segundo a segundo, horas ou dias antes destas ocorrerem, ou seja, ao detectar uma falha, pode ser possível, através da análise dos registros de sensores da aeronave, verificar quais destes alteram seu comportamento esperado, desta forma estas alterações poderiam servir como preditores de falhas. O problema disto é que são muito sensores que registram muitas informações por segundo.

O conceito de big data pode ser facilmente associado a internet e a tentativas das corporações em encontrar nichos de mercados para seus produtos, na aviação big data pode ser relacionada a toda a informação gerada pela aeronave através de seus muitos sensores que, com o correto processamento destas grandes quantidades de informações, aliado aos históricos de falhas registradas anteriormente, em fase de manutenção preventiva ou mais crítica, pode torna-se uma importante ferramenta para assistência aos pilotos e comandantes.

Sistemas de assistentes inteligentes são o próximo passo desta evolução tecnológica, e quem sabe um dia reduzir os riscos de acidentes por falhas mecânicas a quase zero. Seria muito interessante durante uma viagem a aeronave interromper momentaneamente os afazeres do comandante para avisá-lo que seria prudente que a revisão prevista para daqui a duas semanas fosse adiantada em pelo menos cinco dias pois, conforme registros anteriores, um conjunto de sensores apresentou anomalias preditoras de uma falha no sistema elétrico da aeronave.

Esta realidade está próxima, porém necessita de mais tempo para chegar ao mercado de aeronaves, ainda há um trajeto longo a ser percorrido, traçado por muita classificação e análise de dados, até que se alcance resultados cientificamente comprovados que possam ser preditores e indicadores de falhas.

A próxima geração de aeronaves está a caminho, resta saber se as companhias aéreas aceitarão o custo mais elevado para melhorar a segurança e reduzir os riscos de acidentes, tornando a aviação comercial ainda mais confiável para quem viaja e mais segura para quem nela trabalha. 